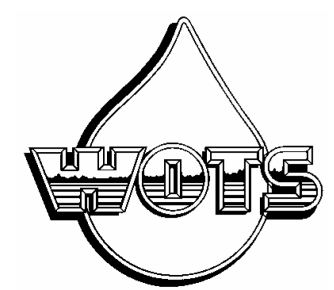

\title{
Phosphorus Loading and Compositional Characteristics in Eight-Mile Run Watershed, Wisconsin
}

\section{by William F. James, Harry L. Eakin, and John W. Barko}

PURPOSE: The purpose of this research was to describe and quantify biologically labile and refractory phosphorus runoff in Eight-Mile Run, a small watershed in west-central Wisconsin that is impacted by dairy livestock management.

BACKGROUND: There is a need to manage eutrophication problems in Corps of Engineers receiving waters by reducing losses of soils and associated soluble nutrients (primarily phosphorus) in intensively managed agricultural land-use settings that are hydrologically sensitive to runoff. In many agricultural watersheds, livestock is contained in relatively small areas for long periods of time, leading to overgrazing and loss of perennial cover, disruption of the soil surface, and the buildup of nutrients in the soil via manure incorporation that can become a source to receiving waters during runoff events. Bank erosion and decimation of adjacent buffer strips by livestock that is allowed to forage along tributaries can further exacerbate soil and nutrient erosion and runoff. To forecast the impacts of watershed rehabilitation and Best Management Practices (BMPs) on hydraulic and nutrient loadings, models need to be refined to address the impacts of various land-use practices such as livestock production and management on concentrations and loads of sediment and important nutrients like nitrogen and phosphorus in rivers and streams draining watersheds.

The objectives of this study were to examine phosphorus $(\mathrm{P})$ loads and $\mathrm{P}$ compositional characteristics for a small tributary (Eight-Mile Run) impacted by a dairy livestock operation. Fractionation procedures were used to identify biologically labile (i.e., recyclable via chemical transformations or directly available for biological uptake) and refractory (i.e., unavailable for biological uptake and subject to permanent burial) species of phosphorus running off the watershed that can have an impact on water quality conditions and eutrophication of receiving waters in the basin.

METHODS: Eight-Mile Run is a small tributary inflow located in the Upper Eau Galle River Basin, a $123-\mathrm{km}^{2}$ watershed in west-central Wisconsin that exhibits multiple land uses (Ashby 1985). Land uses in the 264-ha Eight-Mile Run watershed are co-dominated by woodlots (28 percent), agricultural row crops (predominantly corn; 33 percent), and CRP (Conservation Reserve Program; 35 percent; Figure 1). Although livestock containment areas in this watershed represent only $\sim 4$ percent of the area, this land use is concentrated in one location near the base of the watershed (Figure 1). Land uses in the livestock area include two barnyard-feedlot settings and several fenced forage areas that encompass Eight-Mile Run. Livestock are free to trample the banks and walk in the Run during the summer. No vegetated buffer strips occur along the tributary in the livestock area; grazed forage areas and barnyard feedlots extend directly to the tributary's banks.

An automated water sampling and flow gauging station was established upstream of the run's confluence with the Upper Eau Galle River (Figure 1). Stage height was recorded at 15-min intervals using an ISCO 6700 sampler with a 730 bubbler module (ISCO Incorporated, Lincoln, Nebraska). 


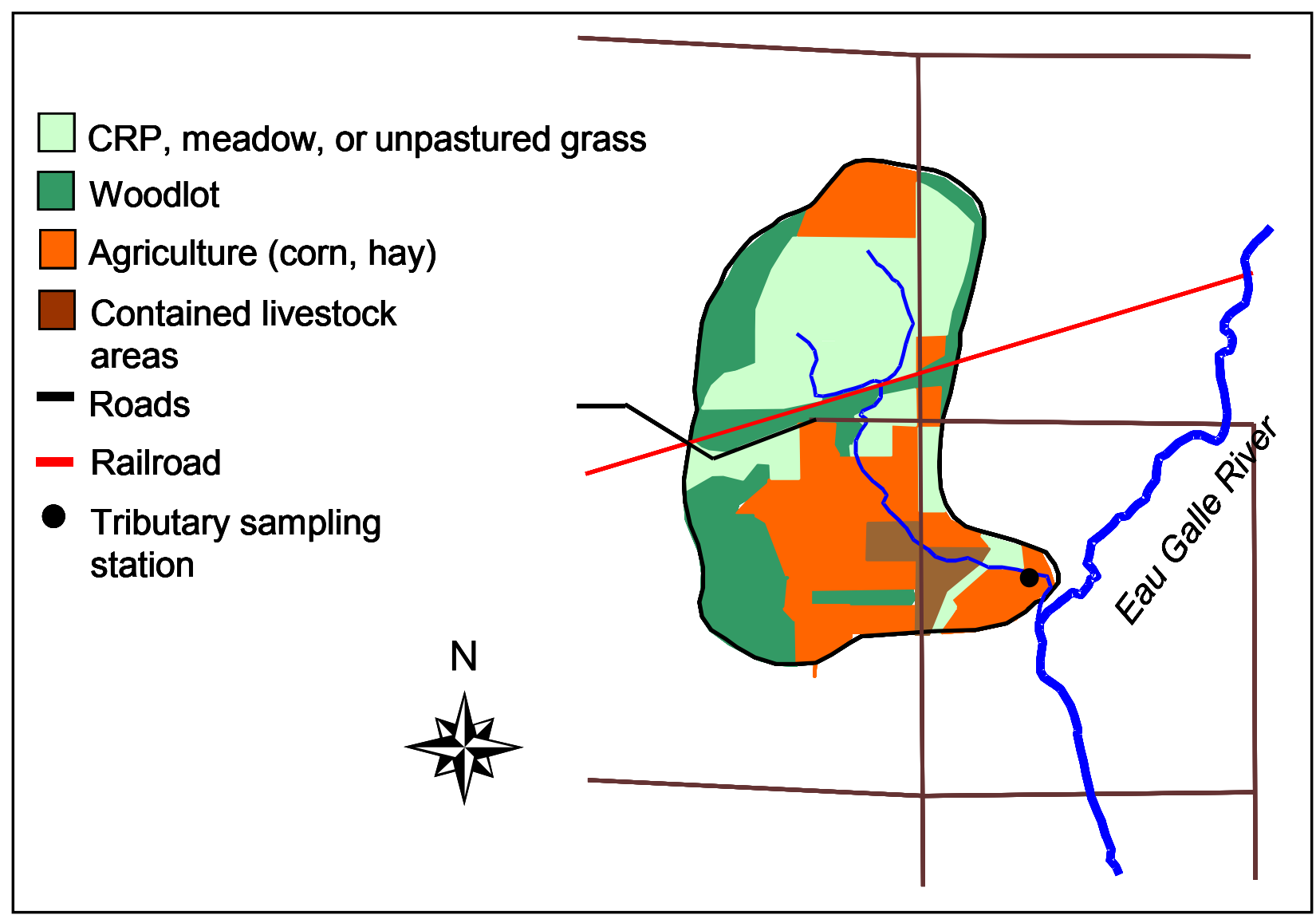

Figure 1. Eight-Mile Run watershed and land uses

A stage-discharge relationship was determined over a variety of flow regimes to convert stage height to volumetric flow. A precipitation gauge (Dataloggers; Model S-162), placed near the watershed, monitored rainfall over 15-min intervals. Flows and precipitation were monitored in both watersheds between May and October 2002.

Water samples were collected at short time intervals (15-30 min) with automated sampling equipment (ISCO Model 6700 samplers), and composited into daily, flow-weighted samples for chemical analysis. In the laboratory, a portion was filtered through a $0.45-\mu \mathrm{m}$ filter for soluble constituent determination. Soluble reactive P (SRP) was analyzed using automated analytical techniques (Lachat QuikChem ${ }^{\circledR}$ Autoanalyzer, Hach Company, Lachat Div., Loveland, CO). Total and total soluble P were analyzed colorimetrically using Lachat QuikChem ${ }^{\circledR}$ procedures following digestion with alkaline potassium persulfate according to Ameel et al. (1993). For particulate components, sample aliquots were retained on glass fiber filters (Gelman Metricel; $2 \mu$-nominal pore size). Sequential fractionation of inorganic $\mathrm{P}$ in the sediments was conducted according to Hieltjes and Lijklema (1980) and Nürnberg (1988) for the determination of ammonium-chloride-extractable particulate $P$ (PP; loosely bound P), bicarbonate-dithionite-extractable PP (i.e., iron-bound PP), sodium hydroxide-extractable P (i.e., aluminum-bound PP), and hydrochloric acid-extractable P (i.e., calcium-bound PP). A subsample of the sodium hydroxide extract was digested with potassium persulfate to determine nonreactive sodium hydroxide-extractable PP (Psenner and Puckso 1988). 
Labile particulate organic-polyphosphate PP was calculated as the difference between reactive and nonreactive sodium hydroxide-extractable P. PP remaining on the filter after the hydrochloric acid extraction was digested with potassium persulfate and $5 \mathrm{~N}$ sulfuric acid for determination of refractory organic PP. Each extraction was filtered through a $0.45-\mu \mathrm{m}$ filter, adjusted to $\mathrm{pH} 7$, and analyzed for SRP using the ascorbic acid method (American Public Health Association (APHA) 1998).

Loosely bound and iron-bound PP are biologically labile and directly available for uptake by biota. These PP fractions can also be recycled via $\mathrm{eH}$ and $\mathrm{pH}$ reactions and equilibrium processes. Labile organic-polyphosphate PP is biologically labile and can be mineralized by bacteria to inorganic forms that can be taken up by biota (Jensen and Anderson 1992). A portion of this fraction is also thought to be tied up in microbial biomass as polyphosphates (Hupfer et al. 1995). In receiving waters, bacteria residing in the sediment can transform stored polyphosphates to ortho-phosphate for uptake by other biota via anaerobic hydrolysis (Gächter et al. 1988, Gächter and Meyer 1993).

To measure P sorption characteristics of suspended sediment loads, the remaining composited sample from an individual storm was centrifuged at $500 \mathrm{~g}$ and decanted to separate particulate from soluble phases. Sediment aliquots $\left(\sim 500 \mathrm{mg} \mathrm{L}^{-1}\right.$ dry weight equivalent) were subjected to a series of $\mathrm{SRP}\left(\mathrm{KH}_{2} \mathrm{PO}_{4}\right.$ as SRP) standards ranging from 0 to $1.0 \mathrm{mg} / \mathrm{L}$ (i.e., $0,0.125,0.250,0.500$, and $1.00 \mathrm{mg} \mathrm{L}^{-1}$ ) for examination of $\mathrm{P}$ adsorption and desorption over a $24-\mathrm{hr}$ period. The concentration of suspended particles used in the study fell within the range of concentrations occurring naturally in the watershed during periods of storm inflow. Untreated tap water from the laboratory was used as the water medium because it was phosphate-free and exhibited very similar cationic strength, conductivity, and $\mathrm{pH}$ to that of surface water from the Upper Eau Galle River. Chloroform (0.1 percent) was added to inhibit biological activity (Detenbeck and Brezonik 1991). The equilibrium systems, containing sediment, tap water, and known concentrations of SRP, were shaken uniformly for $24 \mathrm{hr}$ and then sampled and analyzed for SRP (APHA 1998). The equilibrium systems were maintained under oxic conditions at a $\mathrm{pH}$ of $\sim 8.0$ to 8.3 and a temperature of $\sim 20^{\circ} \mathrm{C}$ during the shaking process.

The change in SRP mass (i.e., initial SRP - final SRP; mg) over the 24-hr period was divided by the dry mass equivalent of wet sediment used in the experiment to determine the quantity of $\mathrm{P}$ desorbed or adsorbed (mg P kg${ }^{-1}$ sediment). These data were plotted as a function of the equilibrium SRP concentration after $24 \mathrm{hr}$ of incubation to determine the linear adsorption coefficient $\left(\mathrm{K}_{\mathrm{d}} ; \mathrm{L} \mathrm{kg}^{-1}\right)$, the equilibrium $\mathrm{P}$ concentration (EPC; $\mathrm{mg} \mathrm{P} \mathrm{L}^{-1}$; the point where net sorption is zero), and the native adsorbed $\mathrm{P}\left(\mathrm{S}_{\mathrm{o}}\right.$; mg $\mathrm{P} \mathrm{kg}{ }^{-1}$ sediment; initial $\mathrm{P}$ adsorbed to the sediment). The $\mathrm{K}_{\mathrm{d}}$ and $\mathrm{S}_{\mathrm{o}}$ were calculated using regression analysis as the slope and the $\mathrm{y}$-intercept, respectively, from linear relationships between final SRP concentrations and the quantity of $\mathrm{P}$ sorbed at low equilibrium concentrations (Pant and Reddy 2001). The EPC was calculated as $\mathrm{S}_{\mathrm{o}}$ divided by $\mathrm{K}_{\mathrm{d}}$.

Daily constituent loading rates were determined using the software program FLUX (Walker 1996). Constituent loading was calculated either as the product of a flow-weighted average concentration and mean flow over different flow strata or by linear regression analysis of concentration versus flow. 
RESULTS: Several storms occurred between May and September 2002 (Figure 2). A maximum daily precipitation of $64.5 \mathrm{~mm} \mathrm{~d}^{-1}$ occurred in late August. Daily precipitation for the summer period averaged $4.5 \mathrm{~mm} \mathrm{~d}^{-1}$. Peaks in mean daily flow coincided with periods of peak daily precipitation throughout the summer period. During a dry period between July and early August, mean daily flow diminished to zero. Eight-Mile Run became completely dry during this period, indicating an absence of groundwater base flow. The average runoff coefficient over the summer period was $0.1 \mathrm{~cm} \mathrm{~d}^{-1}$.

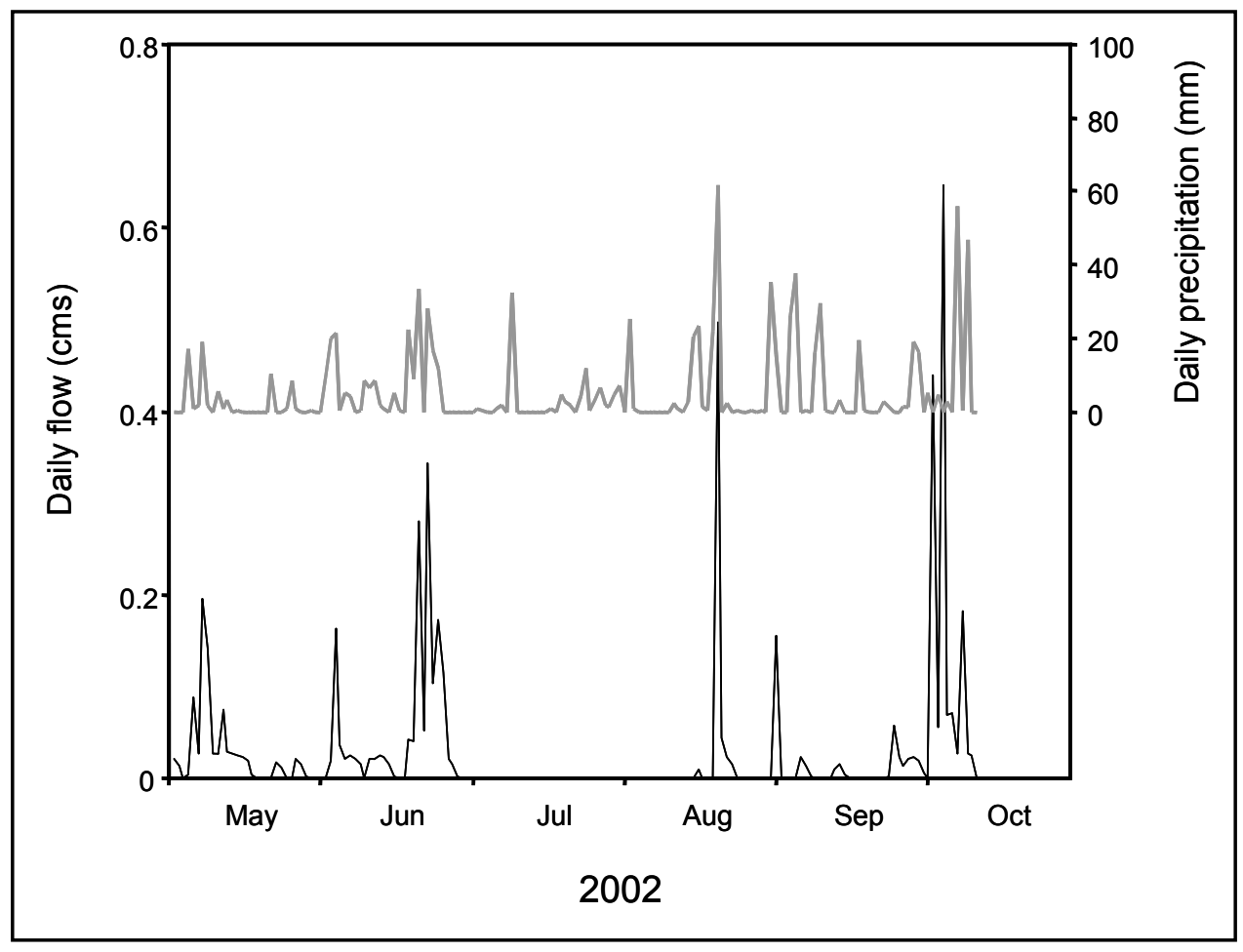

Figure 2. Variations in daily flow and precipitation for Eight-Mile Run between May and October 2002

Peaks in precipitation and flow coincided with elevated loading of total particulate and soluble $\mathrm{P}$ (Figure 3) and labile and refractory particulate P species (Figure 4). Overall, summer total P loads from the Eight-Mile Run watershed were composed of predominantly soluble P (Figure 5). Although particulate $\mathrm{P}$ accounted for only $\sim 37$ percent of the total $\mathrm{P}$ load, 65 percent of this material was biologically labile (i.e., loosely bound, iron-bound, and labile organic-polyphosphate PP). Thus, soluble P and labile particulate P loading from the Eight-Mile Run watershed, considered to be available for biological uptake either directly or indirectly via recycling pathways, accounted for 87 percent of the total $P$ load.

Positive linear relationships existed between mean daily flow and $\mathrm{K}_{\mathrm{d}}, \mathrm{S}_{\mathrm{o}}$, and the EPC of total suspended solids loads from the Eight-Mile Run Watershed (Figure 6). These patterns suggested that runoff and delivery of particles enriched in adsorbed $\mathrm{P}$ increased as a function of increasing flow. Mean summer $P$ equilibrium characteristics of the total suspended solids are shown in Figure 7. At SRP concentrations below $0.5 \mathrm{mg} \mathrm{L}^{-1}$, desorption of P occurred; above this concentration, adsorption 


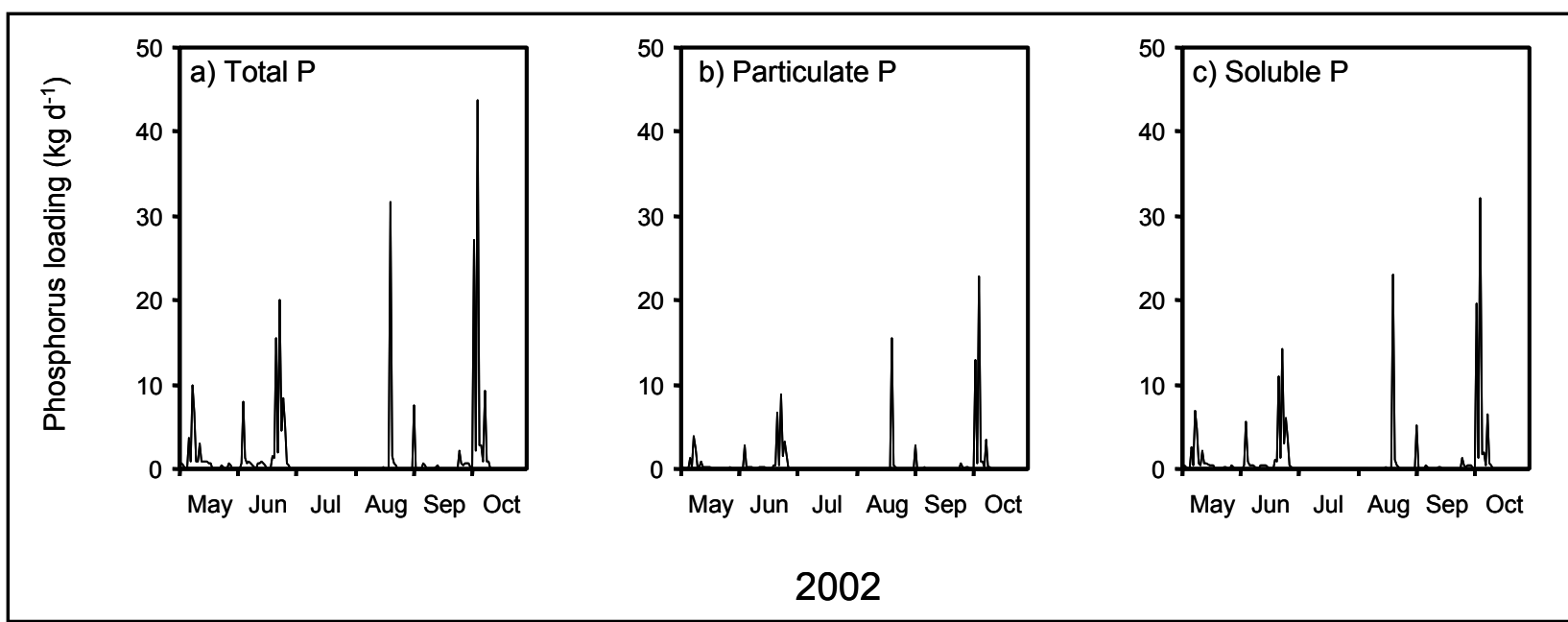

Figure 3. Variations in mean daily total phosphorus $(P)$, particulate $P$, and soluble $P$ loadings for EightMile Run

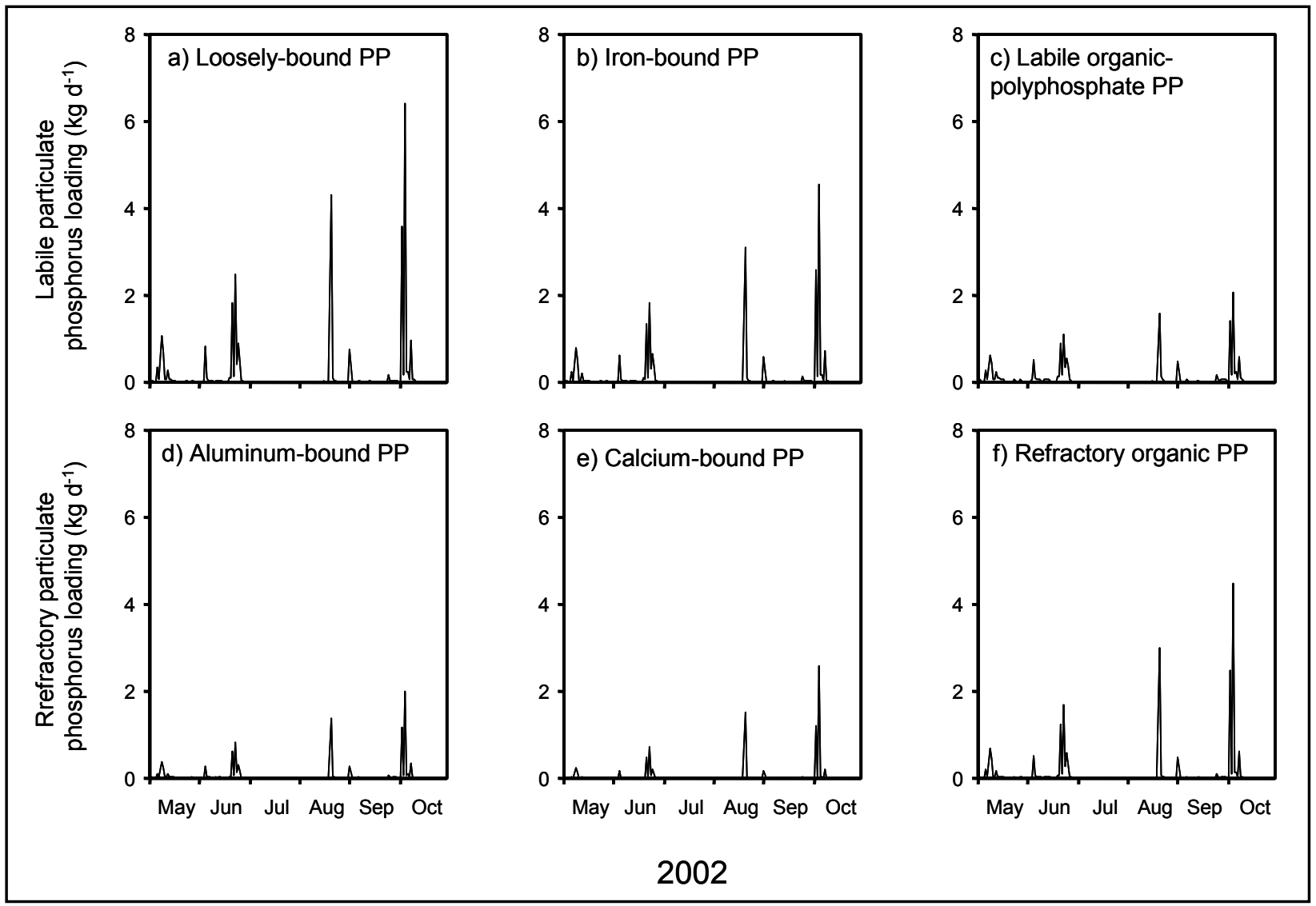

Figure 4. Variations in labile particulate phosphorus loading (upper panel; a-c) and refractory particulate phosphorus loading (lower panel; d-f) for Eight-Mile Run 


\section{Eight-Mile Run}

Calcium-bound PP - 3\%

$0.019 \mathrm{mg} \mathrm{L}^{-1}$

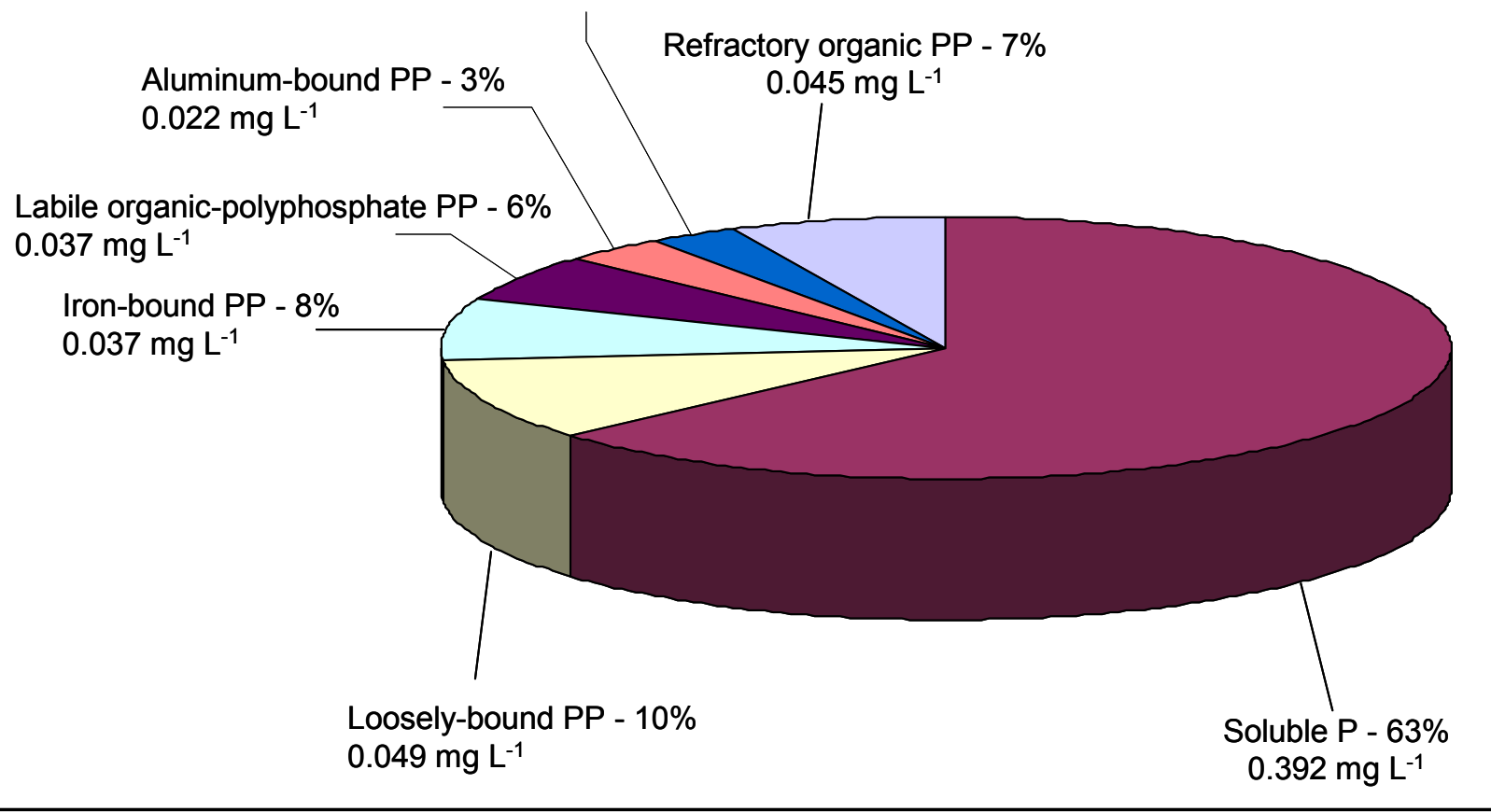

Figure 5. Compositional characteristics of total phosphorus $(P)$ loads from Eight-Mile Run. Loosely bound, iron-bound, and labile organic-polyphosphate particulate $\mathrm{P}(\mathrm{PP})$ are biologically labile and can be used directly by biota or recycled. Aluminum-bound, calcium-bound, and refractory organic PP are refractory and not available for biological uptake

of $\mathrm{P}$ onto particles occurred. Overall, mean $\mathrm{K}_{\mathrm{d}}$ was moderate compared to $\mathrm{K}_{\mathrm{d}}$ for other aquatic sediments (Olila and Reddy 1993, Reddy et al. 1996, Pant and Reddy 2001), suggesting moderate to high buffering capabilities for phosphate under conditions of P disequilibrium (Table 1). The EPC and $\mathrm{S}_{\mathrm{o}}$ were very high for total suspended solids loads and reflected equilibrium characteristics of runoff from livestock containment areas versus other land uses (Table 1). The mean summer EPC concentration $\left(0.414 \mathrm{mg} \mathrm{L}^{-1}\right)$ was very similar to the mean soluble P concentration of loads from the watershed (0.392 $\mathrm{mg} \mathrm{L}^{-1}$; Figure 5), suggesting regulation of aqueous $\mathrm{P}$ by equilibrium reactions with suspended particles.

DISCUSSION: Soluble P concentrations in the runoff of Eight-Mile Run were very high even though more than 60 percent of the watershed exhibited CRP and woodlot land uses. These patterns were likely attributed to P solubilization from soils with high manure content (Sharpley et al. 1994) located in the dairy livestock containment areas adjacent to the tributary. In general, soils in dairy livestock containment areas of both Eight-Mile Run and the Upper Eau Galle watershed exhibited mean Mehlich-3 P and water-extractable P concentrations of $1600 \mathrm{ppm}$ and $50 \mathrm{ppm}$, respectively 


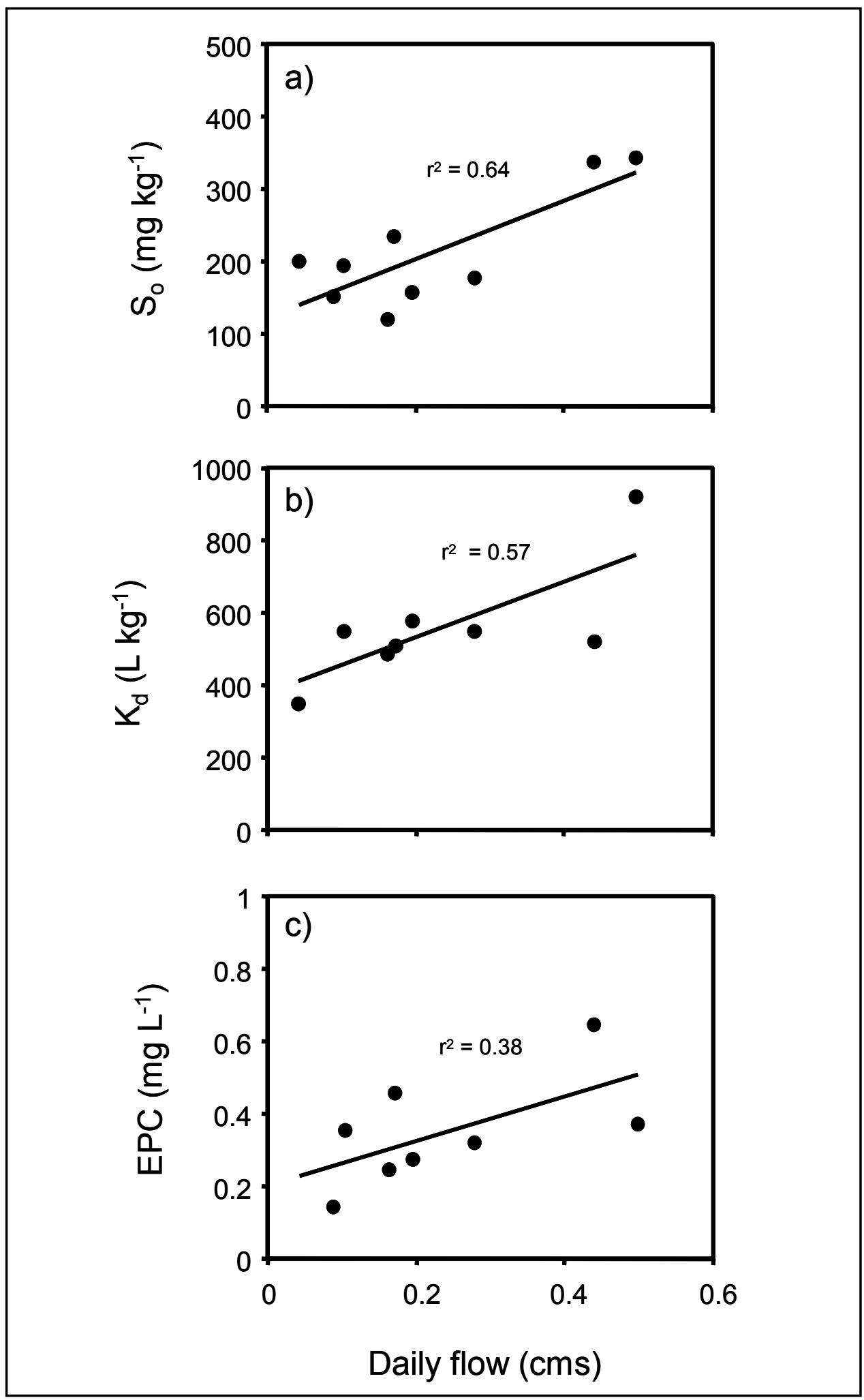

Figure 6. Relationships between daily flow and a) native adsorbed phosphorus $\left.\left(\mathrm{S}_{\mathrm{o}}\right), \mathrm{b}\right)$ the linear adsorption coefficient $\left(\mathrm{K}_{\mathrm{d}}\right)$, and c) the equilibrium phosphorus concentration (EPC) for suspended solids in the runoff of Eight-Mile Run 


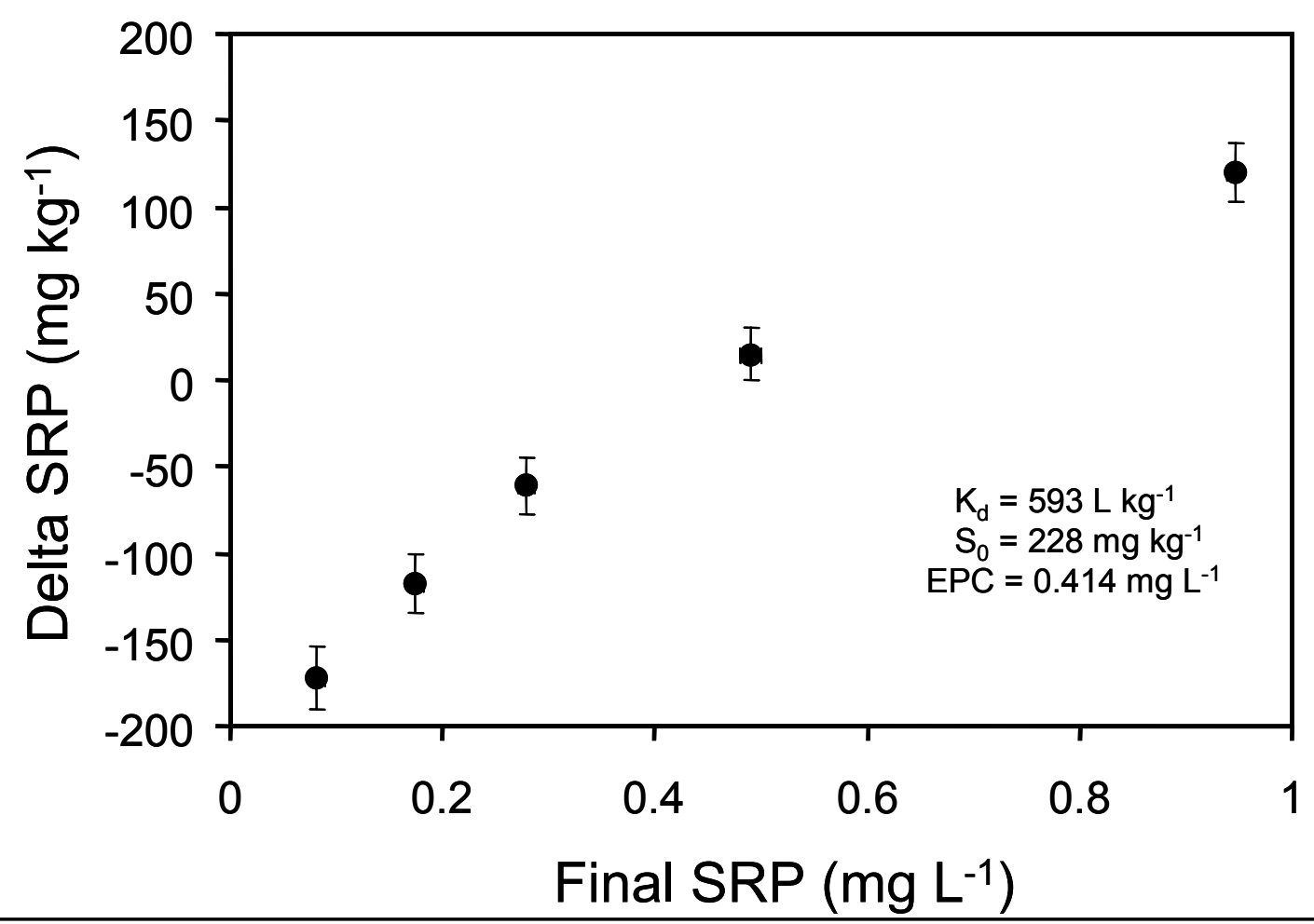

Figure 7. Relationships between the final soluble reactive phosphorus (SRP) concentration and the change in ambient SRP (delta SRP) over a 24-hr period for suspended solids collected in the runoff of Eight-Mile Run during May through October 2002. A negative delta SRP indicates net desorption of phosphorus from suspended particles while a positive delta SRP indicates net adsorption of phosphorus onto suspended particles. $\mathrm{K}_{\mathrm{d}}=$ linear adsorption coefficient, $\mathrm{S}_{\mathrm{o}}=$ native adsorbed phosphorus, and EPC = equilibrium phosphorus concentration

\begin{tabular}{|c|c|c|c|}
\hline \multicolumn{4}{|c|}{$\begin{array}{l}\text { Table } 1 \\
\text { Comparison of EPC, } \mathrm{P}\left(\mathrm{S}_{\mathrm{o}}\right) \text {, and } \mathrm{K}_{\mathrm{d}} \text { for Total Suspended Solids, Eight-Mile Run } \\
\text { Watershed, May-October } 2002^{1}\end{array}$} \\
\hline Land Use & $\mathrm{EPC}, \mathrm{mg} \mathrm{L}^{-1}$ & $\mathrm{~S}_{\mathrm{o}}, \mathrm{mg} \mathrm{kg}^{-1}$ & $\mathrm{~K}_{\mathrm{d}}, \mathrm{L} \mathrm{kg}^{-1}$ \\
\hline Eight-Mile Run & $0.414(0.050)$ & $228(24)$ & $593(61)$ \\
\hline Barnyards & $0.674(0.129)$ & $230(30)$ & $451(85)$ \\
\hline Cornfields & $0.179(0.022)$ & $107(20)$ & $633(62)$ \\
\hline Woodlots & $0.026(0.013)$ & $20(8)$ & 950 ( 121) \\
\hline
\end{tabular}

(James, unpublished data), indicating marked enrichment of readily solubilized (crop available) phosphorus in these soils due to manure incorporation. Equilibrium processes between total suspended solids and aqueous phases may have also played a role in regulating very high SRP concentrations in the runoff. Although particulate $\mathrm{P}$ concentrations were lower relative to soluble $\mathrm{P}$, $\sim 60$ percent of this component was comprised of biologically labile $\mathrm{P}$ forms that were reactive to 
equilibrium processes. There was also marked similarity between the mean summer EPC of suspended particles in the runoff and the mean, flow-weighted concentration of SRP of the runoff, suggesting equilibrium control of SRP. Reddy et al. (1978) also found that manure amendments increased the EPC of soils tremendously.

Overall, 87 percent of the P runoff from Eight-Mile Run was in a biologically labile form and potentially available for biological uptake either directly or via recycling pathways. Loads from this subwatershed and many other agriculturally managed subwatersheds enter the Upper Eau Galle River Basin, which drains into Eau Galle Reservoir (see James et al. (in publication (a)). This Corps impoundment, used for recreation and flood control, is eutrophic, exhibits excessive algal blooms (dinoflagellates and blue-green bacteria; James et al. (1991)), and has experienced beach closures in summer due to high fecal coliform counts (James, unpublished data). Substantial reductions in P loading from this watershed and other livestock production land-use areas might be achieved by implementing several different BMP's (Best Management Practices). The streambanks of Eight Mile Run could be protected from livestock degradation by fencing to prevent access to the tributary. Constricted livestock crossings could be built in one or two locations if there was a need to pasture cattle on both sides of the run. Vegetated buffer strips established along the tributary corridor in the livestock containment areas would trap eroded soils in the runoff from entering the tributary more efficiently during storm events. Finally, relocating feedlots to areas that are less susceptible to hydrologic runoff could decrease soluble $\mathrm{P}$ loading to the tributary. There is a need for watershed models that accurately predict loadings of biologically labile $\mathrm{P}$ and $\mathrm{P}$ transformations via equilibrium processes between particulate and aqueous phases in intensively managed watersheds such as Eight-Mile Run. Such models will be beneficial in forecasting the impacts of BMP on loading reduction to Corps receiving waters.

ACKNOWLEDGMENTS: The authors gratefully acknowledge T. Brunner, M. Daniels, K. Johnson, L. Pommier, and M. Weiss of the Eau Galle Aquatic Ecology Laboratory, ERDC, for sampling, fractionation, and chemical analyses.

POINTS OF CONTACT: This technical note was written by Messrs. William F. James and Harry L. Eakin of the Eau Galle Aquatic Ecology Laboratory, Environmental Laboratory (EL), Engineer Research and Development Center (ERDC), and Dr. John W. Barko, EL, ERDC. For additional information, contact the manager of the Water Operations Technical Support (WOTS) Program, Mr. Robert C. Gunkel (601-634-3722; Robert.C.Gunkel@erdc.usace.army.mil). This technical note should be cited as follows:

James, W. F., Eakin, H. L., and Barko, J. W. (2003). "Phosphorus loading and compositional characteristics of Eight-Mile Run Watershed, Wisconsin," Water Quality Technical Notes Collection (ERDC WQTN-PD-14), U.S. Army Engineer Research and Development Center, Vicksburg, MS. www.wes.army.mil/el/pubs/ wqtncont.html 


\section{REFERENCES}

Ameel, J. J., Axler, R. P., and Owen, C. J. (1993). "Persulfate digestion for determination of total nitrogen and phosphorus in low nutrient waters," Am. Environ. Lab., 8-10.

American Public Health Association. (1998). Standard methods for the examination of water and wastewater. 20th ed.

Ashby, S. L. (1985). "Part III: Watershed description." Limnological studies at Eau Galle Lake, Wisconsin, Environmental and Water Quality Operational Studies. Technical Report E-85-2, R. H. Kennedy, ed., U.S. Army Engineer Waterways Experiment Station, Vicksburg, MS.

Detenbeck, N. E., and Brezonik, P. L. (1991). "Phosphorus sorption by sediments from a soft-water seepage lake. 1. An evaluation of kinetic and equilibrium models," Environ. Sci. Technol. 25:395-403.

Gächter, R., and Meyer, J. S. (1993). "The role of microorganisms in mobilization and fixation of phosphorus in sediments," Hydrobiologia 253, 103-121.

Gächter, R., Meyer, J. S., and Mares, A. (1988). "Contribution of bacteria to release and fixation of phosphorus in lake sediments," Limnol. Oceanogr. 33, 1542-1558.

Hjieltjes, A. H., and Lijklema, L. (1980). "Fractionation of inorganic phosphorus in calcareous sediments," J. Environ. Qual. 8, 130-132.

Hupfer, M., Gächter, R., and Rüegger, H. (1995). "Polyphosphate in lake sediments: 31P NMR spectroscopy as a tool for its identification," Limnol. Oceanogr. 40:610-617.

James, W. F., Barko, J. W., and Taylor, W. D. (1991). "Effects of alum treatment on phosphorus dynamics in a northtemperate reservoir," Hydrobiologia 215:231-241.

James, W. F., Eakin, H. L., Ruiz, C. E., and Barko, J. W. "Variations in field-scale nitrogen and phosphorus concentrations in the runoff as a function of land-use practice," (in publication (b)), U.S. Army Engineer Research and Development Center, Vicksburg, MS.

James, W. F., Ruiz, C. E., Barko, J. W., and Eakin, H. L. "Longitudinal loading and nutrient compositional gradients in an agriculturally-managed watershed in west-central Wisconsin," (in publication (a)), U.S. Army Engineer Research and Development Center, Vicksburg, MS.

Jensen, H. S. and Andersen, F. Ø. (1992). "Importance of temperature, nitrate, and $\mathrm{pH}$ for phosphate release from aerobic sediments of four shallow, eutrophic lakes," Limnol. Oceanogr. 37, 577-589.

Nürnberg, G. K. (1988). "Prediction of phosphorus release rates from total and reductant soluble phosphorus in anoxic lake sediments," Can. J. Fish. Aquat. Sci. 44, 960-966.

Olila, O. G., and Reddy, K. R. (1993). "Phosphorus sorption characteristics of sediments in shallow eutrophic lakes of Florida," Arch. Hydrobiol. 129, 45-65.

Pant, H. K., and Reddy, K. R. (2001). "Phosphorus sorption characteristics of estuarine sediments under different redox conditions," J. Environ. Qual. 30, 1474-1480.

Psenner, R., and Puckso, R. (1988). "Phosphorus fractionation: Advantages and limits of the method for the study of sediment P origins and interactions," Arch. Hydrobiol. Biel. Erg. Limnol. 30, 43-59.

Reddy, G. Y., McLean, E. O., Hoyt, G. D., and Logan, T. J. (1978). "Effects of soil, cover crop, and nutrient source on amounts and forms of phosphorus movement under simulated rainfall conditions," J. Environ. Qual. 7, 50-54. 
Reddy, K. R., Fisher, M. M., and Ivanoff, D. (1996). "Resuspension and diffusive flux of nitrogen and phosphorus in a hypereutrophic lake," J. Environ. Qual. 25, 363-371.

Sharpley, A. N., Chapra, S. C., Wedepohl, R., Sims, J. T., Daniel, T. C., and Reddy, K. R. (1994). "Managing agricultural phosphorus for protection of surface waters: Issues and options. J. Environ. Qual. 23, 437-451.

Walker, W. W. (1996). "Simplified procedures for eutrophication assessment and prediction: User manual," Instruction Report W-96-2, September, 1996, U.S. Army Engineer Waterways Experiment Station, Vicksburg, MS.

NOTE: The contents of this technical note are not to be used for advertising, publication, or promotional purposes. Citation of trade names does not constitute an official endorsement or approval of the use of such products. 